\title{
Distribution of CD8 and CD20 Lymphocytes in Chronic Periapical Inflammatory Lesions
}

\author{
Christine Kalvelage PHILIPPI ${ }^{1}$ \\ Pantelis Varvaki RADOS ${ }^{2}$ \\ Manoel SANT'ANA FILHO ${ }^{2}$ \\ João Jorge Diniz BARBACHAN ${ }^{2}$ \\ Onofre Francisco de QUADROS ${ }^{2}$ \\ ${ }^{1}$ Department of Oral Pathology, School of Dentistry, UNIVALI, Itajai, SC, Brazil, and UNOESC, Joaçaba, SC, Brazil \\ ${ }^{2}$ Department of Oral Pathology, School of Dentistry, UFRGS, Porto Alegre, RS, Brazil
}

\begin{abstract}
The objective of this study was to investigate the distribution of CD8+ and CD20+ lymphocytes in chronic periapical inflammatory lesions. A total of 90 periapical inflammatory lesions (chronic abscesses, abscessed cysts, and inflammatory cysts) were evaluated. The biotin-streptavidin immunohistochemical technique was used to identify cytotoxic/suppressor T-lymphocytes (CD8) and B-lymphocytes (CD20). Age ranged from 10 to 67 years. Patients between 26 and 45 years old (54.4\%), females (52.2\%), and white patients (74.4\%) were more frequently affected. CD8+ cell distribution was as follows: 1 ) fibrous capsule: diffuse in $58.8 \%$ of chronic abscesses and absent in $64.1 \%$ of abscessed cysts and in $70.6 \%$ of inflammatory cysts; 2 ) infiltration zone: diffuse in $100 \%$ of abscessed cysts and in $82.4 \%$ of inflammatory cysts; 3 ) sub-epithelial zone: absent in $53.0 \%$ of inflammatory cysts and diffuse in $56.4 \%$ of abscessed cysts; 4) suppurative zone: diffuse in $100 \%$ of chronic abscesses and in $97.5 \%$ of abscessed cysts. CD20+ cell distribution was as follows: 1) fibrous capsule: absent in $100 \%$ of inflammatory cysts, in $94.8 \%$ of abscessed cysts, and in $88.3 \%$ of chronic abscesses; 2 ) infiltration zone: diffuse in $100 \%$ of abscessed cysts and in 53\% of inflammatory cysts; 3 ) sub-epithelial zone: absent in $58.8 \%$ of inflammatory cysts and focal in $46.2 \%$ of abscessed cysts; 4 ) suppurative zone: diffuse in $100 \%$ of abscessed cysts and in $100 \%$ of chronic abscesses. The distribution of the lymphocytic infiltrate in the lesions was usually diffuse for both types of lymphocytes.
\end{abstract}

Key Words: antigens, B-lymphocytes, T-lymphocytes, periapical diseases, immunohistochemistry, inflammation.

\section{INTRODUCTION}

Periapical inflammatory lesions are a frequent pathology and, in most cases, a consequence of dental caries (1). This type of lesion develops as an immune reaction triggered by the presence of bacteria in the root canal and bacterial toxins in the periapical region (2).

The immune complex is formed by cells whose main function is to recognize antigens that penetrate the organism and neutralize and/or destroy them (3). Several authors have reported different concentrations and distribution patterns of T- and B-lymphocytes in periapical inflammatory lesions (4-6).

According to Torabinejad (7), neutrophils, plasma cells, and lymphocytes may be found in the proliferating epithelium of apical cysts, while the for- mation of a cavity in the epithelium of periapical lesions is mediated by immunological reactions and associated with the discontinuity of epithelial lining in most cysts. Gao et al. (6) reported that lymphocytes are frequently found in diffuse infiltrates in periapical cysts. The number of CD4+ cells is usually the same or higher than the number of CD8+ cells, which have often been found inside the epithelium. A positive CD4/CD8 cell ratio indicates the complex nature of the immune interaction in periapical lesions. Several factors, such as the stage of the lesion, may affect this ratio.

Reports in the literature confirm the involvement of the immune system in periapical inflammatory processes. The purpose of our study was to identify CD8+ and CD20+ lymphocytes in periapical inflammatory lesions with epithelial proliferation and/or 
suppuration and to describe their pattern of distribution.

\section{MATERIAL AND METHODS}

From October 1999 to April 2000, 170 periapical inflammatory lesion specimens were collected by several dental surgeons and sent to the Oral Pathology Laboratory at Universidade Federal do Rio Grande do Sul, Brazil, for histopathologic examination following different procedures (apicoectomy and extraction). Of these specimens, 90 ( 34 chronic abscesses $-37.8 \%$; 17 inflammatory cysts $-18.9 \%$; 39 abscessed cysts $43.3 \%$ ) were included in our study. Inclusion criteria required that the biopsy records contained information about the patient's sex, race, and age. Another inclusion criterion was the presence of both the central and the peripheral portions with the capsule of the lesion.

The study was approved by the Ethics Committee of the School of Dentistry of Universidade Federal do Rio Grande do Sul, Brazil.

The following histopathologic criteria were adopted for the diagnosis of lesions in this study: chronic abscess (CA) was defined as a cavity containing pus and surrounded by a fibrous capsule; inflammatory cyst (IC) was defined as a pathologic cavity partially or

Table 1. CD8+ lymphocyte distribution in the zones studied.

\begin{tabular}{lccc}
\hline & Focal & Diffuse & Absent \\
\hline Fibrous capsule & & & \\
IC & $11.7 \%$ & $17.7 \%$ & $70.6 \%$ \\
AC & - & $35.9 \%$ & $64.1 \%$ \\
CA & - & $58.8 \%$ & $41.2 \%$ \\
Infiltration zone & & & \\
IC & $11.8 \%$ & $82.4 \%$ & $5.8 \%$ \\
AC & - & $100 \%$ & - \\
CA & - & - & - \\
Sub-epithelial zone & & & \\
IC & $29.4 \%$ & $17.6 \%$ & $53.0 \%$ \\
AC & $18.0 \%$ & $56.4 \%$ & $25.6 \%$ \\
CA & - & - & - \\
Suppurative zone & & & - \\
IC & - & - & - \\
AC & $2.5 \%$ & $97.5 \%$ & - \\
CA & - & $100 \%$ & \\
\hline
\end{tabular}

$\mathrm{IC}=$ inflammatory cyst; $\mathrm{AC}=$ abscessed cyst $\mathrm{CA}=$ chronic abscess. completely lined by stratified epithelium and surrounded by a fibrous capsule with an inflammatory infiltrate; abscessed cyst (AC) was defined as a pathologic cavity partially or completely lined by stratified epithelium, surrounded by a fibrous capsule, and containing pus both in the cavity and in the connective tissue of the lesion. The specimens were fixed in $10 \%$ formalin for 24 hours at room temperature and embedded in paraffin according to the protocol followed at the laboratory.

A Leica RM2155 (Nussloch, Germany) microtome was used to cut $3 \mu \mathrm{m}$-thick sections for microscopy. We obtained three sections from each block and mounted each on a separate slide.

One of the slides was stained with hematoxylineosin for histopathologic diagnosis. The other two sections were mounted on silanized slides (S3003, Dako). We used biotin-streptavidin immunoassay to perform the immunoperoxidase technique.

CD8 and CD20 markers identified cytotoxic/ suppressor T- and B-lymphocytes, respectively. The analysis of distribution of the antibody-stained cells was performed under optical microscopy at x 40 magnification by one examiner for all slides. Lymphocytic infiltrate was classified as diffuse (DI), focal (FO), or absent (AB) in the following zones: fibrous capsule (FC), inflammatory cell infiltration zone (IZ), sub-

Table 2. CD20+ lymphocyte distribution in the zones studied.

\begin{tabular}{lccc}
\hline & Focal & Diffuse & Absent \\
\hline Fibrous capsule & & & \\
IC & - & - & $100 \%$ \\
AC & - & $5.2 \%$ & $94.8 \%$ \\
CA & $11.7 \%$ & - & $88.3 \%$ \\
Infiltration zone & & & \\
IC & $47.0 \%$ & $53.0 \%$ & - \\
AC & - & $100 \%$ & - \\
CA & - & - & - \\
Sub-epithelial zone & & & \\
IC & $29.5 \%$ & $11.7 \%$ & $58.8 \%$ \\
AC & $46.2 \%$ & $30.8 \%$ & $23.0 \%$ \\
CA & - & - & - \\
Suppurative zone & & & - \\
IC & - & - & - \\
AC & - & $100 \%$ & - \\
CA & - & $100 \%$ & \\
\hline
\end{tabular}

$\mathrm{IC}=$ inflammatory cyst; $\mathrm{AC}=$ abscessed cyst $\mathrm{CA}=$ chronic abscess. 
epithelial zone (SEZ), and suppurative zone (SZ).

\section{RESULTS}

Patients were grouped according to age, which ranged from 10 to 67 years. Patients more frequently affected by these lesions were those between 26 and 45 years old (54.5\%), followed by patients older than 45 $(23.3 \%)$ and younger than $26(22.2 \%)$. Periapical inflammatory lesions were more frequent in female patients $(52.2 \%)$ and in white patients $(74.4 \%)$.

The results of the analysis of CD8+ and CD20+ distribution in the different zones of each specimen were as follows: CD8+ lymphocytes in the fibrous capsule were diffusely distributed in most chronic abscesses (58.8\%) and absent in most abscessed cysts $(64.1 \%)$ and inflammatory cysts $(70.6 \%)$. Diffuse distribution of CD8+ cells in the infiltration zone of inflammatory cells (Figure 1) was found in all abscessed cysts (100\%) and in most inflammatory cysts (82.4\%). Sub-epithelial CD8+ lymphocytes were not found in most inflammatory cysts $(53.0 \%)$ and were diffusely distributed in most of the abscessed cysts (56.4\%). In the suppurative zone, CD8+ lymphocytes were diffusely distributed in all chronic abscesses $(100 \%)$ and in most abscessed cysts (97.5\%) (Table 1).

CD20+ cells were absent in the fibrous capsule of all inflammatory cysts (100\%) and in most abscessed

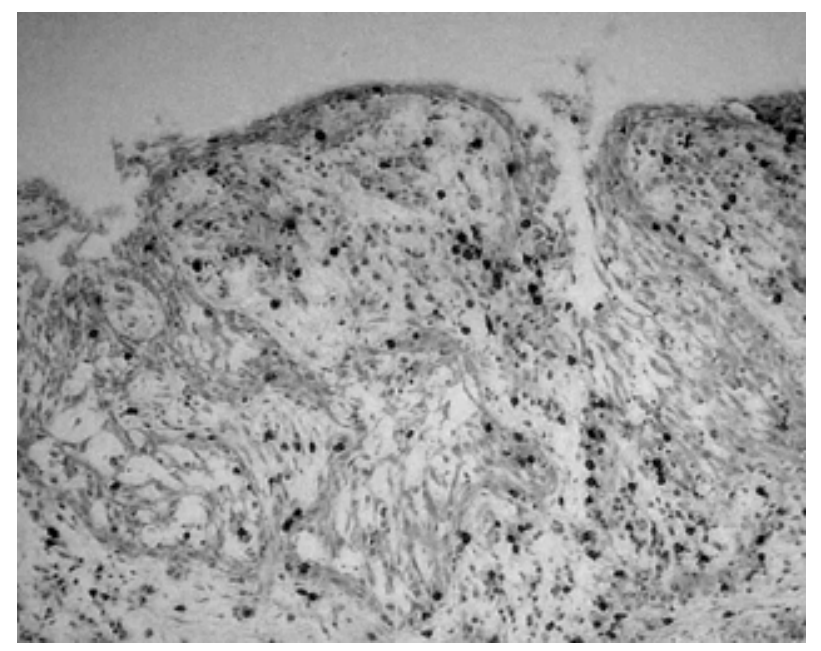

Figure 1. Diffuse distribution of CD8+ lymphocytes in the infiltration zone of inflammatory cells. Part of the epithelial lining can be observed in the upper part of the figure (x100 magnification). cysts $(94.8 \%)$ and chronic abscesses (88.3\%). Diffuse distribution of B-lymphocytes in the infiltration zone was found in all abscessed cysts (100\%) and in most inflammatory cysts (53\%). Sub-epithelial CD20+ lymphocytes were not found in most inflammatory cysts (58.8\%) and were focally distributed in most abscessed cysts $(46.2 \%)$. In the suppurative zone, CD20+ lymphocytes were also diffusely distributed in all abscessed cysts $(100 \%)$ and chronic abscesses (100\%) (Table 2, Figure 2).

\section{DISCUSSION}

Periapical tissues have components that are necessary for the cellular and humoral immune response, and that participate in the development of periapical pathologies. The humoral immune response is the main immune mechanism against extracellular microorganisms and their toxins, since antibodies bind to them to help in their destruction. Cellular immunity promotes the destruction of cells infected by intracellular microorganisms, since antibodies are incapable of attacking these antigens (14). T- and B-lymphocytes are programmed to respond to specific antigens. According to the data mentioned above, and since there is a large variety of antigens, it is understandable that cytotoxic/ suppressor T-lymphocytes and B-lymphocytes are found inside the lesions.

Immunohistochemical reactions with $\mathrm{CD} 8$ and CD20 markers for the identification of cytotoxic/suppressor T- and B-lymphocytes, respectively, allowed us

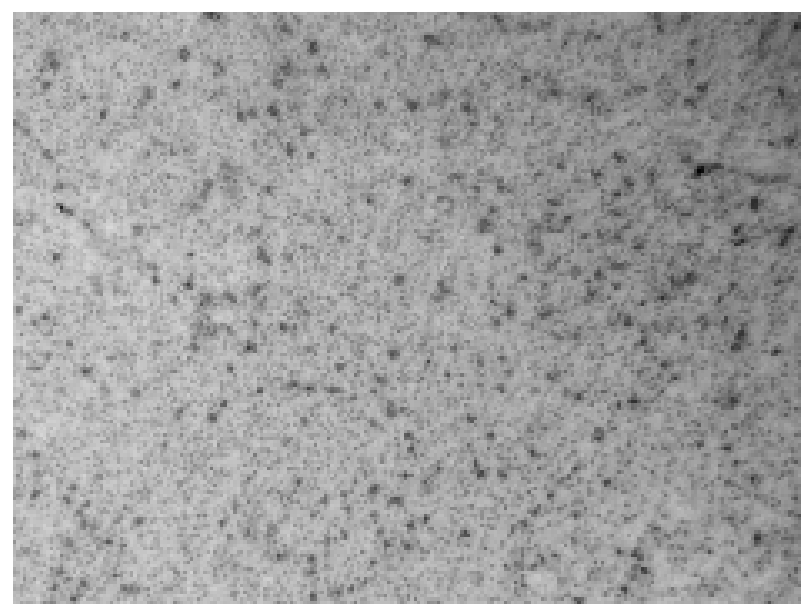

Figure 2. Diffuse distribution of CD20+ cells in the suppurative zone of a chronic abscess (x100 magnification). 
to identify T- and B-lymphocytes in the different pathologies studied. We thus agree with several authors $(4,15,16)$ who report that cellular and humoral immune mechanisms are involved in the pathogenesis of chronic periapical lesions.

Our analysis of the distribution of lymphocytic infiltrates in the different periapical lesions showed that CD8+ cells were absent from the fibrous capsule in $56.6 \%$ of the lesions, and diffusely and focally distributed in $41.1 \%$ and $2.3 \%$, respectively. CD20+ lymphocytes were absent from the fibrous capsule in $93.3 \%$ of the periapical lesions. The lower concentration of inflammatory infiltrate in the capsule of periapical lesions is supported by the findings of Alavi et al. (21), who reported that this inflammatory infiltrate is statistically higher in lesions of teeth not treated endodontically when compared with treated teeth. These findings suggest that when the microbiologic agents are removed from the root canal defensive cells are lowered in number in apical lesions.

When comparing suppurated and non-suppurated lesions, we noted that the fibrous capsule was free from lymphocytic infiltrate in most non-suppurated lesions. According to Cohen (17), the capsule of fibrous connective tissue in most periapical cysts is infiltrated by chronic inflammatory cells. We can thus infer that the fibrous capsule - the outermost portion of the lesion and the farthest from the aggression - has more cells involved in remodeling and is practically free from specific and/or nonspecific immune cells.

The mean distribution of sub-epithelial CD8+ and CD20+ lymphocytes was diffuse (37\% and $21.2 \%$ ), focal (23\% and $37.8 \%)$, and even absent (34\% and $34 \%$ ) in the periapical cystic lesions studied, which shows that there is no predominant pattern of distribution. In inflammatory cysts, the sub-epithelial zone was free from CD8+ and CD20+ lymphocytes in 53\% and $58.8 \%$ of the specimens, respectively. In most abscessed cysts, however, CD8+ lymphocytes were distributed diffusely (56.4\%), and CD20+ lymphocytes were distributed focally (46.2\%). According to Gao et al. (6), most T-lymphocytes were located near the epithelial lining: CD4+ cells were observed around the epithelium, and CD8+ cells were more frequently found inside the epithelium. These authors suggest that immune reactions may be responsible for the proliferation of epithelium. The presence of CD8 + and CD68+ cells in apical lesions, was studied by de Oliveira Rodini and
Lara (22), and the distribution of CD8+ cells in cystic apical lesions are mainly difuse, and more concentrated in the inner part near the epithelial lining of these lesions. According to these authors, these findings represent an active role of the CD8+ cells in the stabilization of these diseases. According to Meghji (18), the endotoxins in the radicular cyst fluid, released by the necrotic dental pulp, have an important role in the pathogenesis of this lesion, and, according to Johannessen (19), subepithelial inflammatory infiltrates indicate that the cystic fluid containing antigens can maintain the local inflammatory process. Torabinejad (7), however, believes that most periapical cysts have a discontinued epithelial lining. These findings led us to suppose that the distribution and the concentration of lymphocytes are directly associated with the presence and concentration of antigens, since the discontinuity of the epithelium allows the contact of antigens with the immune cells of the lesion in the cystic fluid. In our opinion, lymphocyte distribution is primarily associated with the dynamics of the antigenic stimuli and secondarily associated with epithelial proliferation.

The results of our study show that the distribution of lymphocytic infiltrates in abscessed cysts follows a diffuse pattern all over the infiltration zone. In inflammatory cysts, $\mathrm{CD} 8+$ lymphocytes were also distributed diffusely (82.4\%), and CD20+ lymphocytes were distributed diffusely and focally in $53 \%$ and $47 \%$ of the lesions, respectively. Our findings contradict those reported by Cymerman et al. (20) and Gao et al. (6) who reported that T-lymphocytes were distributed focally.

We diagnosed 34 (37.8\%) chronic abscesses and $56(62.2 \%)$ cystic lesions (39 abscessed and 17 nonabscessed). No periapical granuloma was found. Many authors (8-10) disagree about the incidence of periapical inflammatory lesions. We agree with Langeland et al. (11) in that these differences may be attributed to the different microscopic criteria adopted in the evaluation of periapical lesions. The use of serial sections (8) is required for the histopathologic diagnosis of inflammatory lesions.

Currently, there is no consensus about the histopathologic definition of a periapical lesion. According to Syrjanen et al. (12), a periapical cyst is a lesion with proliferation of the stratified epithelium, with or without a cavity; according to Lin et al. (13), a periapical cyst is a pathologic epithelium-lined cavity surrounded by fibrous connective tissue. 
In conclusion, antigens, no matter what their nature, are present throughout the periapical inflammatory lesion; consequently, lymphocytes are also found throughout the lesion so as to neutralize and destroy those antigens, independently of whether there is epithelial proliferation or not.

\section{ACKNOWLEDGEMENTS}

The authors wish to thank to Mrs. Isabel Lauxen, histology technician of the Oral Pathology Laboratory, FO-UFRGS, for her help with the immunohistochemical procedures.

\section{RESUMO}

O objetivo deste estudo foi o de investigar a distribuição de linfócitos CD8+ e CD20+ em lesões inflamatórias periapicais. Para tanto foram estudados 90 casos entre abscessos crônicos, cistos abscedados e cistos inflamatórios. A tecnica de imunohistoquímica pelo método da estreptavidina-biotina foi utilizada para identificar linfócitos T citotóxico/supressor (CD8) e linfócito B (CD20). Dentre os resultados encontrados notou-se uma distribuição das células CD8+ da seguinte forma: 1) difusa na capsula fibrosa dos abscessos crônicos $(58,8 \%)$ e ausente nos cistos abscedados $(64,1 \%)$ e cistos inflamatórios $(70,6 \%) ; 2)$ zona infiltrativa: difusa nos cistos abscedados (100\%) e cistos inflamatórios $(82,4 \%)$; 3 ) zona subepitelial: ausente nos cistos inflamatórios $(53,0 \%)$ e difusa nos cistos abscedados $(56,4 \%) ; 4)$ zona de supuração: difusa nos abscessos crônicos (100\%) e cistos abscedados (97,5\%). As células CD20+ apresentavam a seguinte distribuição: 1) cápsula fibrosa: ausente nos cistos inflamatórios (100\%), cistos abscedados $(94,8 \%)$ e abscessos crônicos $(88,3 \%)$; 2) zona infiltrativa: difusa nos cistos abscedados $(100 \%)$ e cistos inflamatórios $(53 \%)$; 3 ) zona subepitelial: ausente nos cistos inflamatórios $(58,8 \%)$ e focal nos cistos abscedados $(46,2 \%)$; 4) zona de supuração: difusa nos cistos abscedados $(100 \%)$ e abscessos crônicos (100\%). Em conclusão é possível afirmar que a distribuição linfocitária é predominantemente difusa para ambos os tipos de linfócitos.

\section{REFERENCES}

1. Sant'Ana Filho M, Rados PV. Lesões apicais. In: Exodontia. Silveira JOL, Beltrão GC. eds. Porto Alegre: Missau, 1998. p. 275-285.

2. Neville BW, Damm DD, Allen CM, Bouquort JR. Oral and Maxillofacial Pathology. Philadelphia: WB Saunders, Chapter 3,
1995.

3. Siqueira Jr JF, Dantas CJS . Mecanismos celulares e moleculares da inflamação. Rio de Janeiro: Medsi, 2000.

4. Torabinejad M, Kettering JD. Identification and relative concentration of $\mathrm{B}$ and $\mathrm{T}$ lymphocytes in human chronic periapical lesions. J Endod 1985;11:122-125.

5. Kontiainen S, Ranta H, Lautenschlager I. Cells infiltrating human periapical inflammatory lesions. J Oral Pathol 1986;15:544-546.

6. Gao Z, Mackenzie IC, Rittman BR, Korszun AK, Williams DM, Cruchley AT. Immunocytochemical examination of immune cells in periapical granulomata and odontogenic cysts. J Oral Pathol 1988;17:84-90.

7. Torabinejad M. The role of immunological reactions in apical cyst formation and the fate of epithelial cells after root canal therapy: a theory. Int J Oral Surg 1983;12:14-22.

8. Quadros OF. Incidência de cistos em processos apicais. Rev Fac Odontol P Alegre 1982;4:175-176.

9. Stockdale CR, Chandler NP. The nature of the periapical lesion a review of 1,108 cases. J Dent 1988;16:123-129.

10. Ramachandran Nair PN, Pajarola G, Schroeder HE. Types and incidence of human periapical lesions obtained with extracted teeth. Oral Surg Oral Med Oral Pathol 1996;81:93-102.

11. Langeland K, Block RM, Grossman LI. A histopathologic and histobacteriologic study of 35 periapical endodontic surgical specimens. J Endod 1977;3:8-23.

12. Syrjanen S, Tammisalo E, Lilja R, Syrjanen K. Radiological interpretation of the periapical cysts and granulomas. Dentomaxillofac Radiol 1982;11:89-92.

13. Lin LM, Wang SL, Wu-Wang C, Chang KM, Leung C. Detection of epidermal growth factor receptor in inflammatory periapical lesions. Int Endod J 1996;29:179-184.

14. Abbas AK, Lichman AH, Pober JS. Imunologia celular e molecular. 3rd edn. Rio de Janeiro: Revinter, 2000.

15. Stern MH, Dreizen S, Mackler BF, Levy BM. Isolation and characterization of inflammatory cells from the human periapical granuloma. J Dental Res 1982;61:1408-1412.

16. Stashenko P, Yu SM. T helper and T suppressor cell reversal during the development of induced rat periapical lesions. J Dental Res 1989;68:830-834.

17. Cohen MA. Pathways of inflammatory cellular exudate through radicular cyst epithelium: a light and scanning electron microscope study. J Oral Pathol 1979;8:369-378.

18. Meghji S. The role of endotoxin and cytokines in the pathogenesis of odontogenic cysts. Arch Oral Biol 1996;41:523-531.

19. Johannessen AC. Esterase-positive inflammatory cells in human periapical lesions. J Endod 1986;12:284-288.

20. Cymerman JJ, Cymerman DH, Walters J, Nevins AJ. Human T lymphocyte subpopulations in chronic periapical lesions. J Endod 1984;10:9-11.

21. Alavi AM, Gulabivala K, Speight PM. Quantitative analysis of lymphocytes and their subsets in periapical lesions. Int Endod J 1998;31:233-241

22. de Oliveira Rodini C, Lara VS. Study of the expression of CD68+ $\mathrm{T}$ cells in human granulomas and periapical cysts. Oral Surg Oral Med Oral Path Oral Radiol Endod 2001;92:221-227. 